Ionides, Captain W. N. McClean, Mr. J. D. Peattie, Mr. N. J. Pugh, Mr. L. A. Rhodes, Prof. L. Dudley Stamp and Mr. C. A. Wilson, with, as secretary, Mr. M. R. P. Gregson. The terms of reference of the Committee are to "advise on the Surface Water Survey of Great Britain, on the progress of the measures undertaken, and on further measures required, and, in particular, to make an annual report on the subject". The object of the Survey is to make available to government departments, water undertakers, industry, agriculture and to all who need it, information about the yield, behaviour and quality of the water resources of Great Britain. For the present the Committee will be concerned in the main with surface water. The field-work will be undertaken by the new river boards, which are given wide powers for the purpose, and by water users.

\section{National Foundation for Scientific Research, Brussels}

THE twenty-first annual report of the National Foundation for Scientific Research, Brussels, covering the year 1947-48, includes the customary lists of members of the Council, bureau and scientific commissions, and details of research grants made during the year and of publications during 1946-47 and 1947-48. There is also an analysis of the grants made since the creation of the Foundation in 1927 by subjects and by institutions, as well as the first report from the Inter-University Institute of Nuclear Physics established in July 1947. The scientific work of the latter Institute at the Brussels centre has been concerned with photographic plate technique and cosmic rays, with X-ray counters, the separation of isotopes by thermo-diffusion and biological studies of the nucleotides of ribonucleic acid with radioisotopes. At the Ghent centre an automatic Wilson chamber has been constructed, and the diffusion of neutrons and a new Geiger-Müller counter have been studied, while at Liège the purification of uranium, the fission products of uranium and their concentration and the use of the photographic plate in nuclear physics have been among the subjects investigated. At Louvain, the separation of isotopes, the preparation of organic compounds of uranium, nuclear isomerism, and fluorine derivatives of uranium, and at Mons vacuum pumps, Geiger counters, sources of ions and electronic apparatus, have received attention. Some of these subjects have also been studied at the Royal Military College. Special grants were made by the Foundation during the year for a study of the effect of monochromatic X-rays on the phases of cellular division (205,000 franes), for the establishment of a Centre of Eastern Belgian Dialectology (150,000 francs), to the committee responsible for the preparation of an onomatological dictionary of ancient France (120,000 francs), to the provisional committee for the study of alimentation and nutrition of the indigenous peoples of the Belgian Congo (200,000 francs), and for the reconstitution of the collection of photographs of Coptic documents and manuscripts $(50,000$ francs $)$.

\section{American Imports of Indian Jute}

AN "Economic Analysis of the American Market for Jute and Jute Manufactures", by D. Ghosh, has been issued as Economic Research Memoir No. 2 by the Indian Central Jute Committee, Calcutta (pp. $36,1949,1.4$ rupees). India is the largest supplier in almost every section of the American jute trade, and although the American market is predominantly one for burlap, there is a large demand for raw jute, and bags and sacks. The study is an attempt to understand the nature of this important market, especially to discover basic relations and interpret broad movements in terms of those relations. While essentially exploratory, it indicates that the aggregate value of imports of jute and jute manufactures into the United States is governed by the same forces as regulate the size of the American national income and determine the value of American imports in general. Moreover, the quantity of the imports changes more or less in the same manner as the physical volume of American industrial production, but the American demand for jute and jute goods tends to increase rather more than proportionately with a rise in the level of income and industrial activity. A statistical note on the demand for hessian in the United States is appended.

\section{Planning in the Fuel Industries}

IN an address to the Fuel Luncheon Club on December 20, Lieut.-Commander C. Powell, administrative secretary of the Parliamentary and Scientific Committee, after describing the way the Committee works and some action taken by it in recent years, dealt more particularly with the fuel industry, on which the Committee has already issued three reports. Commander Powell summarized some of the recent statements on coal production for costs, coal utilization, oil from coal, domestic fuel efficiency and the co-ordination of research in gas, coal and the electricity industries, which appear to constitute a serious challenge both to the Committee and to fuel technologists. Exactly what is the best policy to follow, either in the short term or in the long, appears to be unsettled; but the Parliamentary and Scientific Committee is prepared to consult with the experts concerned. In particular, there is still before the Committee the memorandum prepared in 1947 by the Combustion Appliance Makers Association, which maintained that twelve million tons of coal a year could be saved by introducing efficient centralheating equipment and up-to-date domestic fuel burning appliances.

\section{The Young Gannet}

AxтноUgf a great deal is known about the activities of the young gannet (Sula bassana) from the day of its birth to the day when it takes to the sea, fow observations have been made on its behaviour during the following two or three weeks. During the autumns of 1947 and 1948, G. T. Kay attempted to discover how the young, fat, ungainly bird, which is unable to fly, transforms itself into a powerful flier and slim expert diver capable of feeding itself (British Birds, 42, No. 9; September 1949). Kay's observations indicate that, after the young gannet has reached the sea, it is no longer fed by its parents and sustains itself for many days without food. Having developed its wings and lost its fat, it is able to get up first for short flights and then for longer ones until it is strong on the wing. Exactly how it secures its first meal is not known. Either it must dive on fish instinctively when alone or follow the example of older birds with which it is certain to come in contact. The conspicuous plumage of the older birds is probably of value to the young one in enabling it to pick out feeding birds at a distance. It would be inter. esting to read accounts of the young gannet's behaviour from observers who have witnessed any activity of the young kird in southern waters. 